\title{
"A Melody Before Unknown": The Civil War Experiences of Mary and Amanda Shelton
}

\author{
THERESA R. MCDEVITT
}

DURING THE CIVIL WAR thousands of Union soldiers wounded in battle or stricken with wretched, life-threatening illnesses languished in Union hospitals that were too often unsanitary and impersonal and nearly always dreaded by patients who longed to be cared for by female friends and relatives. Eager to nurse and care for the men who were risking their lives to preserve the Union, thousands of American women traveled to camps and hospitals to provide medical and relief services to Civil War soldiers.

This female invasion of the male-dominated military hospitals included 23-year-old Mary E. Shelton and her 21-year-old sister, Amanda, of Mount Pleasant, Iowa. In July 1864 they could be found in a sweltering Union hospital in Nashville, Tennessee, working as diet kitchen managers for the U.S. Christian Commission, a religious relief organization. They served as adminis-

This article was greatly enhanced by material provided by archivists and librarians at a number of locations. I would particularly like to thank Lynn Ellsworth, archivist at lowa Wesleyan College, who provided information on Mary and Amanda's lives before and after the war; the librarians in Special Collections at the University of Iowa Libraries, who copied the diaries of Amanda, Mary, and Ortus; those at the State Historical Society of Iowa, who assisted me with Annie Wittenmyer's papers, and Amy Leigh, archivist at the Sallie Bingham Center for Women's History and Culture, Perkins Library, Duke University, who sent me information on Mary's communications with Frank Moore.

THE ANNALS OF IOWA 63 (Spring 2004). (C) The State Historical Society of Iowa, 2004. 
trators, coordinating the selection, acquisition, and preparation of food for the sickest patients and training and supervising a cooking staff of enlisted soldiers. When not in the kitchens, the sisters also provided relief and missionary services in the sometimes fetid wards, distributing food and fans, handkerchiefs, newspapers, religious counsel, tracts, and words of cheer. They delighted in such work. Amanda recorded in her diary that she was "living much" and Mary, who had "never enjoyed anything half so much before," later recalled that the "the joy of ministering to the suffering" had filled her heart with "a melody before unknown." ${ }^{1}$

Perhaps as many as 20,000 women participated in Union medical services as nurses or relief agents. ${ }^{2}$ Such women have long been the subject of scholarly investigation. ${ }^{3}$ Elizabeth Leo-

1. Mary E. Shelton, Diary of Mary E. Shelton, 7/15/1864, Papers of the Shelton Family, Special Collections, University of Iowa, Iowa City, Iowa; Rhoda Amanda Shelton, Diary of Rhoda Amanda Shelton, 5/17/1864, ibid. (underscoring in original); Frank Moore, Women of the War: Their Heroism and Self-Sacrifice (Hartford, CT, 1867), 233.

2. Jane E. Schultz, Women at the Front: Hospital Workers in Civil War America (Chapel Hill, NC, 2004), 4.

3. Authors have examined the role of women in Civil War medical and relief services for over a century. Soon after the war, Frank Moore and L. P. Brockett and Mary Vaughan gathered the stories of women who contributed to the war effort. Frank Moore, Women of the War: Their Heroism and Self-Sacrifice (Hartford, CT, 1867); L. P. Brockett and Mary C. Vaughan, Women's Work in the Civil War: A Record of Heroism, Patriotism, and Patience (Philadelphia, 1867). For the next hundred years, biographical studies of noteworthy female nurses and sanitary agents from both sections continued to appear but there was little systematic study of the work of such women. As the centennial of the war was being celebrated, historians began to treat the topic seriously. See Mary Elizabeth Massey, Bonnet Brigades: American Women and the Civil War (New York, 1966). More recently, the flowering of feminist scholarship has produced many excellent studies on secular and religious nurses, physicians, and sanitary agents. For an overview of women in medical services that is unparalleled in its detail and comprehensiveness, see Schultz, Women at the Front: For information on Roman Catholic sisters who nursed the wounded of both sides, see Sister Mary Denis Mather, To Bind up the Wounds: Catholic Nurses in the U.S. Civil War (Westport, CT, 1989). For an overview of female physicians, see Mercedes Graf, "Women Physicians in the Civil War," Prologue: Quarterly of the National Archives and Records Administration 32 (2000), 86-98. For a study of women in the U.S. Santitary Commission, see Jeanie Attie, Patriotic Toil: Northern Women and the American Civil War (Ithaca, NY, 1998). For more bibliographic leads, see Theresa R. McDevitt, "A Place for Women: A Selective Annotated Bibliography on Civil War Women in Medical Services," Bulletin of Bibliography 57 (2000), 1-11. For an 
nard has suggested that the massive war created the need for female laborers in professional occupations closed to them prior to the war. Women took up such employment for a variety of reasons, but they soon discovered that such careers were intrinsically satisfying and also offered adventure, titles, social status, and higher salaries. Men initially resisted the entrance of women into professional occupations, but revised their opinions when women proved their abilities to function effectively in such capacities. Other authors have presented related theories that the war was a "watershed" for women's history and that their work in the war led to greater access to social, educational, and political life in the postwar era, though some have suggested that the transition from wartime work to meaningful postwar careers was easier for some than others. ${ }^{4}$

In spite of the wealth of writing on women in medical services, the work of women in Christian Commission diet kitchens has never been fully explored. ${ }^{5}$ Mary and Amanda Shelton were two of the first, highest placed, and longest serving diet kitchen managers. These articulate and reflective young women recorded their wartime activities and thoughts as they took to the field to save lives and souls in an experimental program that brought women to work as supervisors in the most public of spheres-the military hospital. Facing challenges to their reputation, virtue, and abilities, they struggled, adapted, and succeeded in changing the opinion of medical authorities concerning the potential of women to contribute positively to

excellent historiographical overview of women in the war period, see Drew Gilpin Faust, "'Ours as Well as That of the Men': Women and Gender in the Civil War," in Writing the Civil War: The Quest to Understand, ed. James M. McPherson and William J. Cooper Jr. (Columbia, SC, 1998), 228-40.

4. Elizabeth Leonard, Yankee Women: Gender Battles in the Civil War (New York, 1994), xx-xxv; Mari Jo Buhle, Women and American Socialism, 1870-1920: The Working Class in American History (Urbana, IL, 1981); Massey, Bonnet Brigades. Compare Mary Livermore's smooth evolution to postwar work with Louisa Lee Schuyler's more difficult transition. Attie, Patriotic Toil, 270-71; Wendy Hamand Venet, "The Emergence of a Suffragist: Mary Livermore, Civil War Activism, and the Moral Power of Women," Civil War History 48 (2002), 143-65.

5. Only one recent study has examined the work of the diet kitchen managers and only as a part of a study of the life of Annie Wittenmyer, the creator of the diet kitchen program. Leonard, Yankee Women, 88-103. No studies have examined the lives and work of individual diet kitchen managers. 
medical care in institutional settings and discovered some of the most satisfying work of their lives. When the war ended, they would begin a new struggle to find meaningful work in a peacetime world that offered women fewer opportunities.

THE NEED for the services of Mary, Amanda, and other civilian relief workers was becoming clear even before the war's bloody fighting had begun in earnest. In hastily constructed military camps, new military recruits found poor sanitary conditions, an unhealthy diet, and primitive housing, and many were soon stricken with any of a number of diseases. When the bloody fighting began, the need for civilian medical services became even more urgent.

Iowa women, ineligible to join the Union army, were quick to offer the services they felt they were best suited to provide. Viewing informal care of the sick as a woman's domain and even the best hospitals as pest houses to be avoided at all costs, women, without waiting for an invitation, forced their way into the male domain of military hospitals to assist the sick and wounded. ${ }^{6}$

One of the first to do so was Annie Turner Wittenmyer of Keokuk, Iowa. Already a veteran of social, religious, and educational reform efforts before the war began, she visited Iowa soldiers as soon as they were brought to local hospitals. Moving beyond individual relief work, she spearheaded efforts to organize a community-wide project, the Keokuk Ladies' Soldiers' Aid Society. When the war was only a few weeks old, she set off for the camps of Iowa troops to investigate conditions there and determine their needs. Discovering deplorable conditions and great suffering in camp, Wittenmyer took up her eloquent pen on the soldiers' behalf. To her home society she sent descriptive and compelling reports of unhealthy living conditions, the plight of the soldiers, and the need for civilian donations. When such missives appeared not only in Keokuk's Gate City but also in other newspapers across the state,

6. For the regard for antebellum hospitals and women's informal but highly significant role in medical services, see Ann Douglas Wood, "The War within a War: Women Nurses in the Union Army," Civil War History 18 (1972), 197-200. 
women all over Iowa began sending donations to Wittenmyer and the Keokuk society. ${ }^{7}$

Wittenmyer inspired the trust of Iowa women and became well known. When Iowa's state legislature created official state sanitary agents, Wittenmyer was the only woman named in the bill to serve in that capacity. That official position gave her more authority, power, and prestige, and added to her workload. By the summer of 1863 , her "labors . . . had become so extensive, the field of her operation so wide, and her letters so numerous, that she needed a secretary to relieve her," so she hired Mary E. Shelton of Mount Pleasant, Iowa, to serve as her aide. ${ }^{8}$

Shelton was the daughter of Lucy Carnafix and Orville C. Shelton, both Virginians. After marrying in 1839, the Sheltons, like thousands of other migrants, moved west during the 1840 s and 1850s from Virginia to Ohio and then to Iowa. Born in Parkersburg, Virginia, in 1841, Mary was 18 by 1860 and living in Mount Pleasant, Iowa, with her parents, both 44 . Also in the household were brothers Ortus C., 20, and Charlie, 1, and two younger sisters, Rhoda Amanda, 16, and Nancy, 13.'

Orville C. Shelton was a Methodist minister who transferred to the Iowa Conference in 1852. "A man possessed of the highest Christian principles and best qualities of mind and heart," he settled in Mount Pleasant, a community that offered substantial cultural and educational advantages, including a literary institute and the coeducational Iowa Wesleyan College. ${ }^{10}$ By 1860 , the town was claiming the title, the "Athens of Iowa." The Shelton

7. Benjamin F. Gue, "Annie Turner Wittenmyer," in History of Iowa from the Earliest Times to the Beginning of the Twentieth Century (New York, 1903); Leonard, Yankee Women, 51-53; "Mrs. Annie Wittenmyer," Annals of Iowa 4 (1899), 277-79.

8. Moore, Women of the War, 213; "Mrs. Annie Wittenmyer," 279; Noah Zaring, "Competition in Benevolence: Civil War Soldiers' Aid in Iowa," Iowa Heritage Illustrated 77 (1996), 10-23.

9. Jordon R. Dodd, et al., "Virginia Marriages, 1740-1850," Ancestry.com, www.ancestry.com (accessed 5/23/2004); U.S. Census Office, Population Schedules of the Seventh Census of the United States, Iowa, Henry County, ibid.

10. Edmund H. Waring, History of the Iowa Annual Conference of the Methodist Episcopal Church: Including the Planting and Progress of the Church within Its Limits, from 1833 to 1909, Inclusive (n.p., 1910), 152; Sharon E. Wood, "'My Life Is Not Quite Useless': The 1866 Diary of an Asylum Bookkeeper," Palimpsest 70 (1989), 3. 
family took advantage of the educational opportunities offered in the community. By the time the war began, Ortus, Mary, and Amanda had distinguished themselves through their studies at Iowa Wesleyan. Mary earned both undergraduate and master's degrees there, and she participated in the Ruthean Literary Society. Any undergraduate degree was unusual at the time, especially for women, but Mary earned the more challenging classical degree, suggesting both her intelligence and her love of learning." That she hoped for a full life with broad experiences is suggested by the title of an essay she presented in February 1860: "Take a Box Ticket in the Theatre of Life."

In spite of her exceptional education, Mary's career choices were limited by her gender. After graduation she embarked on a career in teaching, one of the few options for respectable women of the period. She readily quit such work when she received Annie Wittenmyer's invitation to act as her assistant and perform some of the most interesting and rewarding work of her life.

In Wittenmyer's employ, Mary began her "hospital experience" on August 10,1863, accompanying Wittenmyer to the camps and medical facilities of the war's western theater. Their journey began soon after the surrender of Vicksburg, a long and significant siege that claimed the lives of many western soldiers and left many others incapacitated. En route to the field, Mary assisted Wittenmyer by answering letters from the families of sick and wounded soldiers requesting her to visit the soldiers, ascertain their condition, or even determine if they were still alive. Thus, even before she began working in the field, that cor-

11. Mary and Ortus both graduated prior to the war; Ortus was valedictorian. Mildred Bensmiller, "Athens of Iowa," Iowa Wesleyan College, www.iwc.edu/ aboutus/about.htm (accessed 8/16/2004); Historical Sketch and Alumni Record of Iowa Wesleyan College (Mount Pleasant, Iowa, 1917), 41. Mary received an A.B. (Bachelor of Arts) degree, while most other women chose a less challenging, more practical, three-year B.S. degree. According to a study of coeducation in lowa during these years, women made up half of the students in the B.S. program at Iowa Wesleyan and Cornell colleges, but only 12-20 percent of the bachelor of arts students. Prior to the Civil War only three Iowa women had earned a B.A. degree, and not many more (10) had received B.S. degrees. Doris Malkmus, "Origins of Coeducation in Antebellum Iowa," Annals of Iowa 58 (1999), 188-89.

12. Lynn Ellsworth, anchivist, Iowa Wesleyan College, personal e-mail, 5/14/ 2003. 
respondence gave Mary a "wide acquaintance with the sorrows by which the land was burdened." ${ }^{13}$

On the way to the field they stopped at St. Louis, the home of the Western Sanitary Commission and a hub of relief service workers in the region. There they met veteran relief workers and highly placed philanthropic administrators such as James Yeatman, head of the Western Sanitary Commission, an organization with which Wittenmyer worked closely. After making arrangements for relief supplies to be forwarded to them in the field, they hurried on to Helena, Arkansas.

On August 16, 1863, just as the sun was setting, Wittenmyer and Shelton arrived at Helena and went in search of the medical director. When they arrived, he greeted them enthusiastically and explained the dire need for their services. Recently, large numbers of troops had moved rapidly through the area, but not rapidly enough to escape the unhealthy environment. Thousands fell ill. As troops retreated, the sick were left in the care of the medical director, who lacked the accommodations, personnel, and supplies to care for them. The result was 2,000 ailing men languishing in an unhealthy environment with few to care for them and little hope of recovery. ${ }^{14}$

Wittenmyer and Shelton were undaunted by the size of the problem. They sent to St. Louis for more supplies, and the next morning they went to work. They visited hundreds of soldiers who had been suffering in tents or quickly improvised hospitals or lying in the streets in need of clothing, bedding, and food. They labored from sunup to sundown, offering food and drink, bedding and clothing, and working with hospital staff to improve conditions. In these ways the women brought temporal comfort to the soldier. Perhaps even more important, the presence of compassionate women provided emotional comfort. ${ }^{15}$

13. Moore, Women of the War, 214.

14. Ibid., 214-15. Troops stationed at Helena so frequently fell ill with dysentery, typhoid, typhus, and malaria that it became known as "one of the most insalubrious locations in the Union." Major General Henry Halleck suggested that it be abandoned. Rhonda M. Kohl, "This Godforsaken Town': Death and Disease at Helena, Arkansas, 1862-63," Civil War History 50 (2004), 109.

15. One soldier told Mary Shelton, "O, how like my own mother it seemed when you put the cold cloth on my aching head!" Another said, "It does my heart good to see that kind of ladies come to camp." Ibid., 217. 
Although conditions improved, Wittenmyer shared the belief of the soldiers that they had no hope "for speedy recovery unless they could be moved." Hurrying to Memphis, Tennessee, Wittenmyer met with General Stephen Augustus Hurlburt and convinced him to move the sick to northern hospitals, saving many lives. ${ }^{16}$

In this, her "first hospital experience," Mary witnessed one of the worst medical situations of the war and was gratified to see that women in the field could do much to improve it. For the rest of the war, Mary would struggle to rise to the challenges her often perilous new career would offer. As she did, she would gain administrative skills, experience, and a growing sense of what women could contribute to public life.

As Wittenmyer's assistant, she worked closely with one of the state's most famous women and interacted with prominent relief workers and military and political figures. She traveled extensively, corresponded with families all over Iowa, and entered public and political life through active involvement in efforts to increase support for Wittenmyer's fieldwork and to develop asylums for Civil War orphans. Doors opened to her that had been shut to women in the antebellum period, and she experienced great freedom, considerable authority and responsibility, and was able to play an active role in the great national struggle that would decide the fate of the nation.

Mary clearly was exhilarated by this work. While her patriotism, compassion, and religious fervor drove her to assist the soldiers, she also appreciated the larger salary, new acquaintances, broader experiences, and more access to public life than she had had as a schoolteacher. Her satisfaction with the work is clear in a diary that often records that she was "very happy". and "deeply grateful" to have the opportunity to perform this service and "so thankful" that she was "not teaching." 17

Wittenmyer, too, was finding that the war offered her expanding opportunities for satisfying her patriotic and compassionate nature, but also for greatly increased power and status.

16. Ibid., 217-19.

17. Mary Shelton, Diary, 4/22/1864. See entries in Mary Shelton's diary, January-April 1864, for a record of her varied activities. 
During this period she would shift from a state sanitary agent to affiliation with a national organization and leadership in an innovative program that would save the lives of Union soldiers and create a place for women in Union hospitals.

In Wittenmyer's extensive fieldwork, she had discovered that too often hospitals in the field were unable to provide adequate diet for the sick. The result was, as one soldier patient explained, "men that might have grown strong and well with proper nourishment, were daily sinking into the grave." ${ }^{18}$ This problem was one that Wittenmyer felt American women were well suited to solve.

To systematically provide proper diet for soldier, Wittenmyer proposed that independent special diet kitchens be established in the hospitals. Such kitchens would be staffed by soldiers, but run by middle-class women who she believed knew what foods sick men needed and wanted and knew how they could be prepared to most appeal to the ailing. Such women would have the title of "lady managers," suggesting respectability and middle-class status but also the administrative nature of their work. Also suggestive of their professional status were their salaries, which were higher than those paid to female Union nurses. ${ }^{19}$

The program would function under the auspices of the U.S. Christian Commission, a spiritual and temporal relief organization. The commission would provide the infrastructure to carry out a program in diverse locations, provide "delicate" foods and other supplies necessary for the operation of the kitchens, and pay the women for their services. The eternal life of the soldier was also a concern to both Wittenmyer and the Christian Commission, so the kitchen administrators would also serve as missionaries in the wards when circumstances permitted.

The first kitchens opened in the spring of 1864. By the end of the war, they had spread to one hundred locations, employed two hundred women, and served millions of meals. A great success, the program was hailed by both religious and military

18. Moore, Women of the War, 217.

19. Lady managers were paid $\$ 20$ per month, Union nurses $\$ 8$. (For comparison, privates in the Union army received $\$ 13$ per month.) Leonard, Yankee Women, 93; Wittenmyer, "Special Diet Kitchens," 6. 
authorities, including General Grant, who personally visited the kitchens and concluded that they were "an important part of hospital work." ${ }^{20}$

ONE OF THE FIRST WOMEN to enter the hospitals as a "lady manager" was Mary's younger sister Amanda. In March 1864 Wittenmyer invited Amanda to work in the diet kitchens. In April, Wittenmyer sent her a telegram instructing her to meet the seasoned relief agent in Keokuk. Complying with the instructions, Amanda set off on one of the most important journeys of her life.

To do so Amanda had to overcome the objections of friends and loved ones who presented "a wild picture of privations and perils." Caring for sick relatives or making donations to soldiers in the field was considered women's patriotic and Christian duty, but going to work in a Civil War field hospital was viewed by most as madness that could endanger a woman's respectability as well as her health and her life. This daughter of a Methodist minister relied on her deep religious faith and commitment to Christian charity to reject such arguments and set off to save the lives and the souls of Civil War soldiers. ${ }^{22}$

Amanda's friends were not entirely mistaken in warning her that her honor and respectability were at risk if she went to the field. Within days of leaving home, Amanda learned firsthand the perils that might befall female travelers when the drunken captain of the steamer Louisville "insulted" her. The incident "frightened and outraged" her and must have caused her to consider whether she had made the right decision. ${ }^{23}$

But on she went, to Nashville, Tennessee, and then Chattanooga, with other would-be managers, including fellow Iowans Jennie Hagan of Muscatine and a Miss Coggill of Iowa City. ${ }^{24}$ Despite the negative experience on the steamer, Amanda enjoyed the journey, delighting in the scenery on the trip down

20. Wittenmyer, "Special Diet Kitchens," 16; "Mrs. Annie Wittenmyer, " 282-83.

21. Amanda Shelton, Diary, 4/15/1864.

22. Ibid; Burlington Hawk-Eye, 4/23/1864.

23. Amanda Shelton, Diary, 4/15/1864.

24. Moore, Women of the War, 520. 
the river and in visits to sites of military and civil importance in Nashville. She also appreciated the opportunity to meet interesting people, including other relief agents, military personnel, Christian Commission delegates, and even people with national reputations, such as Johnny Clem, the celebrated "Drummer Boy of Chickamauga." Wittenmyer delivered Amanda, Jennie, and Miss Coggill to the Christian Commission Rooms in Chattanooga. There they waited to be summoned to begin work in their first kitchen. ${ }^{25}$

On April 21 an ambulance arrived to take them to a field hospital at the foot of Lookout Mountain. There the women confronted the realities of army life. Their "quarters" were "rough and dirty" and so poorly constructed that they did not keep out the weather. They also discovered that although they were civilians they were expected to abide by military rules from which they felt their special status should exempt them. Thinking longingly of the comfortable homes they had left behind, the women "crushed down despair and disappointment" in an effort to put on a brave face and even "laughed at these deprivations. ${ }^{26}$

The poor quality of their accommodations may have been directly related to the attitude of the surgeon-in-charge, who did "not look upon" their "efforts with any degree of pleasure." In fact, at first he did not allow them to work in the kitchens at all. If they could not work as dietary managers, the women sought at least to fulfill their role as missionaries. When they could get permission from the supervising physicians, they visited the wards to talk with the patients, comfort them, and distribute religious papers in which they had written personal messages.

At first the patients did not greet them with the universal welcome and gratitude they hoped for. Although some of the men received their religious message enthusiastically, others were indifferent to their visits. Amanda faced the new work with some reluctance and apprehension. She was eager to pass on her Christian message and comfort the afflicted, but she was

25. Amanda Shelton, Diary, 4/15/1864.

26. Moore, Women of the War, 520; Amanda Shelton, Diary, 4/17-23/1864.

27. Amanda Shelton, Diary, 4/22/1864. 
intimidated by the prospect of visiting wards filled with suffering men who were strangers to her, particularly when she had to do so alone, without a supervisor or chaperone. Soon, however, she grew more comfortable with such visits, and even came to enjoy the work, although the scenes she witnessed there were sobering. At night she prayed, "God grant that we and mine may be spared from death in a hospital," and expressed her thanks "for life and health and the privilege of doing something to alleviate the dreadful suffering. ${ }^{20}$

This period of relative inactivity lasted for weeks, straining the women's relationship. Bickering broke out. Despite Wittenmyer's strict admonitions that managers must obey all hospital rules, Miss Coggill was so eager to get to work that she urged the younger women to visit the wards even when they did not have the permission of the medical authorities. Amanda and Jennie recognized that such actions would be "inexpedient" and refused. Other frictions emerged. Amanda began to truly dislike Jennie Hagan, concluding that she had "intellect" but no "soul or sympathy"; there was "something about her" that Amanda "could never endure." Amanda recorded that she would be glad when Miss Hagan "leaves us." Amanda also found fault with Miss Coggill, considering her to be a woman with "sympathy" but no "judgment." Considering neither of them her social or intellectual equal, Amanda complained that she was becoming ill from want of "congenial society." She recognized her own limitations, too, as she prayed to be "good and patient," and regretted her "proud disposition." Despite such frictions, when the opportunity to get started in the kitchens finally arrived, they were able to overcome them and work harmoniously together. ${ }^{29}$

The opportunity to get to work in the kitchens arrived in the middle of May when the surgeon-in-charge unexpectedly informed the women that he wanted them to begin their work the next morning. For Amanda, preparing breakfast for 200 patients with less than 24 hours to prepare was a "horrifying" prospect. With few supplies, inadequate kitchen equipment, and an un-

28. Ibid., 4/22/1864.

29. Ibid., 5/2/1864, 5/5/1864, 5/10/1864, 5/12/1864. 
trained cooking staff of soldiers, the task might have daunted even Wittenmyer. But Amanda, "determined to be a 'Hercules" if necessary, was up to the challenge. By 6:30 a.m. the next morning, the kitchen mangers had determined what foods were available and what dishes could be prepared, had taken orders for the patients from the doctors in charge of the wards, determined how much of each dish to prepare, overseen the preparation of the food, and distributed it to the ward masters and nurses. As soon as breakfast was finished, they began to prepare for the mid-day meal. Although the lady managers were exhausted, "the grub," as Amanda ruefully recorded the soldiers called the food, was ready when expected. ${ }^{30}$

Soon the kitchens were running smoothly, and the kitchen staff and managers found their work less taxing. Some aspects of hospital discipline continued to bother the women, however, particularly the need to obey rules that their compassionate natures found repugnant. For example, the women took pains to have the best and most appealing food prepared, but they were not allowed to distribute it directly to soldiers without an order from a doctor. On one occasion a patient came to the back door of the kitchen and complained of hunger. The compassionate Miss Coggill, declaring that she would not refuse him, fed him in the kitchen. Amanda felt that it was the wrong thing to do but acquiesced, concluding that it would be impossible to convince Miss Coggill of "the necessity of having system in all one did" and in being "entirely subservient to the powers that be." While the man was enjoying his meal, the surgeon-in-charge made a surprise visit to the kitchen and discovered the infraction. Miss Coggill defended her actions, declaring "when I get so hardened that I can refuse a hungry sick man his breakfast I will go home." The surgeon assured her that if the scene were repeated, he would be happy to arrange that. Amanda felt the event justified her own dedication to following the rules. ${ }^{3 t}$

After the diet kitchen managers had proven their ability to run the kitchens and work within the hospital bureaucracy,

30. Ibid., 5/15/1864.

31. It was also discovered that the patient was just "playing sick" and had been offered, but refused, a dinner in the wards. Miss Coggill was so mortified by the incident that she became ill. Ibid., 5/15/1864. 
more doctors allowed them to visit the wards. Increased access to the patients also meant increased access to the gruesome condition of those who were the most seriously ill. Amanda recorded her nausea in the face of some of the scenes she witnessed, but she continued to go, distributing reading material, fans, and other comforts to lighten the men's suffering. The patients warmed to the lady managers and said that they were pleased with the improvements in diet and also with the presence of the women in the hospital. Amanda was gratified and noted that the soldiers were "ever attempting to show their gratitude. ${ }^{132}$

By the end of May, Wittenmyer began using seasoned managers to begin new hospitals. She instructed Amanda and Jennie to go to new facilities. For the next five weeks, Amanda moved between diet kitchen sites in the Nashville/Chattanooga area. During that period Amanda experienced new, interesting, enjoyable, and saddening events: she was quartered in an army tent in stormy weather, met a female "Union spy" while riding in a train's boxcar, comforted a dying Christian Commission delegate, and attended the funeral of a friendless northern girl who had come to Nashville to work in the telegraph office. By the end of June, she was in Louisville, Kentucky, not in a hospital, but in a Christian Commission station assigned to help Wittenmyer with her correspondence. ${ }^{33}$

Amanda found her accommodations in Louisville much more comfortable than at the hospitals where she had worked, but she longed to be in the field. In addition, she resented the company of the delegate in charge of the rooms, a Mr. Russell, a "rude and ungentlemanly . . . old bachelor." The relationship between the diet kitchen manager and the delegate did not begin well and deteriorated further after a trip to Joe Holt Hospital, a potential site for a diet kitchen. Amanda recorded in her diary that Russell neglected to hire a conveyance for the trip, forcing her to walk through "dust and dirt." Then, while he went to conduct business elsewhere, he deposited her in a saddler's shop run by a "Dutchman" whose "dirt and smell" she

32. Ibid., 5/15-17/1864, 5/23/1864.

33. Ibid., 5/23/1864, 6/16/1864,6/25/1864. 
found even more unpleasant than the sun and the dust. Even worse, during the discussion with the surgeon-in-charge of the potential diet kitchen site, she felt that Russell treated her statements with such "perfect contempt" that even the surgeon was disturbed by his statements. Amanda was infuriated and made her feelings clear to Russell. ${ }^{34}$

Russell found the incident important (or irritating) enough to report it to Wittenmyer. In his version he told the supervisor that Amanda's comments had ruined their chance to establish a kitchen at Joe Holt, and when he tried to correct the "inexperienced" Amanda by telling her that she had "not helped our cause much," she was unrepentant. Instead, she replied, "Neither was it very polite for a gentleman to contradict a lady." Russell countered that it was she who contradicted him. Amanda concluded that "they would never agree on this or many other points" and refused to discuss the matter further. Russell asked Wittenmyer, "Was not all this trying and provoking?" He then assured her that the next time he went to a hospital to arrange for a diet kitchen, he was sure he would not take Amanda. ${ }^{35}$

Amanda later complained to Wittenmyer of having nothing productive to do at the Louisville Commission rooms and that she could report nothing to Wittenmyer because Russell never thought it "worthwhile to inform" her of what he knew. She couldn't wait to get "out of sight and sound" of Russell. The incident clearly soured the relationship between the delegate and the lady manager and certainly affected their ability to work together cordially for the good of the Commission, the diet kitchen program, and the Civil War soldier. ${ }^{36}$

34. Ibid., 7/6/1864. "Delegates" such as Russell were, in the absence of Wittenmyer or her assistants, the managers' supervisors. These men-religious laymen or Protestant ministers-were closely involved in the diet kitchen program. They traveled with the managers to convince surgeons to accept the kitchens, and they may have had success in doing so where men were reluctant to work with women. They also provided the managers with household and hospital supplies, arranged travel or traveled with the managers in the field or to new hospitals, and ran Christian Commission Homes in war zones, which women stayed in before entering hospitals or before returning home.

35. Russell, Louisville, KY, to Annie Wittenmyer, 7/5/1864, Annie Wittenmyer Papers, State Historical Society of Iowa, Des Moines.

36. Amanda Shelton, Louisville, KY, to Annie Wittenmyer, 6/11/1864, Wittenmyer Papers. 
At least some of the tension that existed between the two grew out of the way the war was shifting gender expectations and the reluctance of both Amanda and Russell to adapt. It is unlikely that Russell was unaware of the treatment expected by middle-class women. Why he acted as he did is not clear. He may have questioned the character of a woman who would come to do such work or he may have felt that such niceties could be suspended during the crisis of war. He certainly thought that Amanda, as an "inexperienced" female, should keep her opinions, if opposed to his, to herself.

Although Amanda had violated prewar gender standards in going to the war zone, she was not willing to accept Russell's failure to treat her with the deference she felt was due a middleclass lady. However, she did not allow prewar notions concerning a lady's place to prevent her from expressing the professional opinions of a seasoned diet kitchen manager. The delegate and the lady manager were not able to navigate the shifting sea of gender expectations and so were unable to work harmoniously together.

SUCH DARK TIMES in Amanda's life were brightened by letters from Mary that reminded her of home and brought "light and song" to her heart. ${ }^{37}$ Meanwhile, Mary, still in Iowa, eagerly read Amanda's letters and "longed restlessly to be in the field. ${ }^{\prime 38}$ Their brother's recent decision to join the Union army, a choice that troubled both sisters, might have made Mary even more eager to leave home. ${ }^{39}$ Mary got her wish on July 2, when she received a letter from Wittenmyer directing her to come to Louisville. Mary's family and friends did not greet the offer with equal delight. Just as Amanda had been warned

37. Amanda Shelton, Diary, 5/1/1864.

38. Mary recorded receiving three letters from Amanda in the field. Mary Shelton, Diary, 5/9/1864,5/11/1864.

39. When Amanda heard that Ortus had enlisted, she recalled that she and others "had with our reluctant love detained him until now." Amanda Shelton, Diary, 5/17/1864. Mary recorded mixed emotions. She had hoped that he would enlist, but when he did, she wrote, "Sad! Sad! Now I can weep with those who weep. My noble brother is going to the army." Mary Shelton, Diary, $4 / 26 / 1864,5 / 18 / 1864$. 
about going to the field, so Mary was advised against it. Mary, too, rejected such counsel, declaring, "Will go, though all object." On July 6 she recorded gleefully, "At last I am getting into my work."

When Mary arrived at Russell's Christian Commission rooms, she was happy to be reunited with Amanda, but could "hardly wait to get to work in the hospital. ${ }^{\prime \prime 1}$ Soon they were both off to establish a kitchen in Nashville's Hospital No. 1. There they worked in kitchens, but their spiritual work in the wards with the soldiers received the most attention in their diaries. By that time, Amanda had overcome her inhibitions concerning ward visiting. She now enjoyed it and felt that the men were deeply grateful for her efforts. Mary recorded that she, too, "talked with many of the sick and wounded soldiers and found them glad to see us." She had "never enjoyed anything half so much before." She even compared it favorably to life in Mount Pleasant, noting "how unimportant everything at home seems. ${ }^{\prime 42}$

The sisters were happiest when in each other's company, but the needs of the service did not allow them to remain together long. Soon Wittenmyer moved them to separate hospitals in the vicinity, but they occasionally were able to meet at Nashville's Christian Commission rooms. Together or alone, as the sisters worked in a variety of settings, gaining the administrative experience necessary to work in complex organizations, their confidence grew. ${ }^{43}$

In August Hannah Smith, who assisted Wittenmyer in adminstering diet kitchens in the region, chose the now experienced Amanda for a particularly difficult assignment. ${ }^{44}$ She was to begin a kitchen in a medical facility run by a doctor who was "opposed to having ladies" in his hospital. Amanda met with the surgeon-in-charge, whom she described as a "savage little man,"

40. Mary Shelton, Diary, 7/2/1864, 7/10/1864.

41. Amanda Shelton, Diary, 7/11/1864; Mary Shelton, Diary, 7/10/1864.

42. Amanda Shelton, Diary, $7 / 14 / 1864,7 / 15 / 1864$.

43. Mary Shelton, Diary, 7/16/1864; Amanda Shelton, Diary, 7/14/1864.

44. Hannah Smith, wife of the Rev. E. P. Smith, ran the Christian Commission rooms in Nashville and supervised diet kitchens in the Department of the Cumberland. Ralph Gordon, "Nashville and the U.S. Christian Commission in the Civil War," Tennessee Historical Quarterly 50 (1996), 100. 
and argued for the opening of the kitchen. She did not allow his reluctant attitude to injure her pride, assuring herself that if "he did not want" her, there were other hospital administrators who did. She eventually succeeded in persuading the doctor to accept two women in his hospital; Amanda Shelton and Libbie Cunningham of Burlington, Iowa, went to Nashville's Hospital No. 14 to open a kitchen. ${ }^{45}$

While Amanda dealt with the delicate situation at No. 14, Mary embarked on a dangerous mission with Annie Wittenmyer to provide relief services to the soldiers fighting with Sherman to take Atlanta. Unfortunately, military operations stalled the relief expedition, making it impossible to proceed until the city had been taken. As soon as possible the relief workers made their way into Atlanta, where Mary witnessed the results of the great struggle. She was glad that she was able to assist the many suffering soldiers in the city, but sad to witness the great "war desolation" that she saw everywhere. ${ }^{46}$

Meanwhile, Amanda remained behind, unable to communicate with her sister. As a result, she experienced "terrible anxiety." On September 14, when the sisters were reunited, Mary recalled the "joy of being with Manda again." But their joy was shortlived. After a few days, Amanda was off on a visit to Mount Pleasant, and Mary was assigned to hospital No. 14 in her sister's place. ${ }^{47}$

Amanda's trip coincided with the homecoming of their soldier brother Ortus, but it was not a happy reunion. By September 24, Amanda wrote to Mary of "his serious illness." A week later, Mary received a telegraph from her father informing her that Ortus was "dangerous" and urging her to come home immediately. Mary did her best to get home as quickly as possible, but transportation was unreliable and her trip was agonizingly slow. On the journey, tortured by the thought that her brother might die before she arrived, she prayed for God to "spare him till I can see him once more." Mary's prayer was granted, and

45. Amanda Shelton, Diary, 7/21/1864; Lemuel Moss, Annals of the United States Christian Commission (Philadelphia, 1868), 683.

46. Mary Shelton, Diary, 8/29/1864-9/9/1864.

47. Amanda Shelton, Diary, 2/11/1865; Mary Shelton, Diary, 9/14-15/1864. 
Ortus lingered for several days. On October 4, Mary made it home and was there when he died. For the next two weeks the sisters prayed for their beloved brother's soul and for the strength to bear the loss. They shared their grief and the rituals of death with their relatives and friends, but soon returned to the hospitals to assuage their sorrow in relief work with other Civil War soldiers. On October 18 they left for Nashville. ${ }^{48}$

Their trip back to the field was disrupted by guerilla raids on trains in Missouri, but they successfully arrived at Hospital No. 14 on October 22. On her return, Mary expressed happiness at being able to work in hospitals: "Our great sorrow seems less, when we can relieve the wants of others.",49

Mary enjoyed the work, but she, too, sometimes regretted the need to observe rules that she felt limited her ability to do the relief and missionary work she had come to do. She would have liked to spend more time in the wards with the patients, but was not allowed free access to the men. She also wrote of her mixed emotions during an incident while she was distributing grapes to patients in hospital wards. The patients loved the grapes; one in particular would have eaten them with relish. Unfortunately, the "officer of the day" rushed up and said that one man's condition would not permit him to eat any. They had to struggle with the man to get the grapes away from him, and after they succeeded, the man wept "bitterly." Mary reported that he was thus "deprived of the only thing he had wanted for months" and that her heart was broken by way he cried. But she did not disobey orders because the "the doctor's word was law." ${ }^{\prime 50}$

Mary would not remain at No. 14 much longer. The diet kitchen program was successful and had grown to include sites throughout the Union-controlled war zone. Given the dispersed location of the kitchens and the difficulties involved in communication, Wittenmyer needed women to assist her in administering the program. Early in December, Wittenmyer asked Mary to serve as a regional administrator in the Mississippi Department. ${ }^{51}$

48. Mary Shelton, Diary, 9/24/1864, 9/30/1864, 10/3-18/1864.

49. Ibid., 10/20-22/1864; Mary Shelton, Nashville, TN, to Mrs. Cole, 11/8/1864, Wittenmyer Papers.

50. Moore, Women of the War, 235.

51. Mary Shelton, Diary, 12/6/1864, 12/8/1864. 
For the remainder of the war, Mary's work was even more peripatetic than Amanda's had been. She traveled from Louisville to Little Rock, from Washington, D.C., to Wilmington, North Carolina, visiting proposed sites and negotiating with hospital administrators to gain permission to begin kitchens and to develop support for them. Then she determined and filled staffing needs for new sites, supervised, assigned, and on occasion trained and worked alongside diet kitchen managers in the kitchens and wards. She accompanied new workers as they came to the field, smoothed over difficulties that emerged at sites under her charge, and kept Wittenmyer informed of what was happening in her department. ${ }^{52}$

While Mary lived a peripatetic life, Amanda remained at No. 14 with Libbie Cunningham from the fall of 1864 until the spring of 1865 . That was the longest period Amanda spent in any hospital, and there she faced her greatest challenges. Although the lady managers were able to gain the confidence of Dr. Fuller, the "savage little man" who had initially been reluctant to have women in his hospital, the close relationship they forged with him became the source of great controversy-nearly enough to drive them from the Christian Commission service.

As early as August, Mary commented on the developing relationship between the diet kitchen managers and Dr. Fuller. She happily reported that he treated the managers quite well, like a "brother," and showed them many "kindnesses." He was very supportive of their work and provided them with any supplies they needed. ${ }^{53}$ The relationship that promoted the smooth operation of the kitchens was not, however, viewed as positively by the Christian Commission delegates and chaplains in the area. Instead, it inspired a storm of gossip, criticism, and accusations of immoral conduct.

Problems began when sometime prior to January 1865, Amanda and Libbie accompanied Dr. Fuller to the theater and then to a private dance held in the hospital. Fuller also took the women on sight-seeing tours of the area, including one in a car-

52. Mary Shelton, Memphis, TN, to Wittenmyer, 3/9/1865, Wittenmyer Papers. 53. Mary Shelton, Diary, 8/12/1864, 8/16/1864, 8/19/1864, 10/22/1864, 10/27/ $1864,10 / 28 / 1864,10 / 31 / 1864,11 / 10 / 1864$. 
riage with a cavalry escort on Amanda's twenty-first birthday. When these incidents came to the attention of a chaplain in the area, he was appalled. Viewing such activities as immoral and inappropriate, he denounced Libbie and Amanda in the press and from his pulpit, and even contacted Annie Wittenmyer about the matter.

When Amanda and Libbie's character came under fire, Wittenmyer at first decided that it would be best to remove them from No.14 and send other women in their place. Amanda agreed to go, but Dr. Fuller was not so cooperative. Launching an offensive, Fuller wrote to Wittenmyer, sending a copy of the letter to Rev. E. P. Smith, the agent in charge of Nashville Christian Commission rooms who had accused Amanda and Libbie of "dancing . . . in the midst of the dead and the dying." Fuller expressed his indignation over the incident and declared that Libbie and Amanda were guilty of no misconduct, that they had been unfairly slandered by "anonymous scribblers," and that he and his wife, too, had been insulted by the charges. He objected to the removal of the young women and declared that if they left, he would accept no other women from the Commission in their stead. ${ }^{55}$

The next step was suggested by regional administrator Hannah Smith (the wife of Rev. E. P. Smith). Hoping to preserve the diet kitchen and the Christian Commission's presence in No. 14, she proposed that they try to discuss the matter with Fuller in the hope of convincing him to accept other managers. Mary, Amanda, Hannah Smith, and Commission delegate Mr. Ewing returned to the hospital, where they were warmly greeted by Dr. and Mrs. Fuller. ${ }^{56}$

Dr. Fuller argued in favor of keeping the women at No. 14, claiming that Wittenmyer's "mind" had been "warped" by the

54. Amanda Shelton, Diary, 2/11/1865; R. George, Nashville, TN, to Bro. Loyd, $2 / 12 / 1865$, and John F. Loyd, Louisville, KY, to Annie Wittenmyer, 2/10/1864, Wittenmyer Papers.

55. T. M. Goodfellow, Nashville, TN, to Annie Wittenmyer, 2/8/1865; Mary Shelton, Louisville, KY, to Annie Wittenmyer, 1/26/1865; R. George, Nashville, TN, to Bro. Loyd, 2/12/1865; S. Fuller, U.S.N. Hosp. No. 14, to Annie Wittenmyer, 1/22/1865, all in Wittenmyer Papers.

56. Mary Shelton, Louisville, KY, to Annie Wittenmyer, 1/26/1865, Wittenmyer Papers. 
chaplain or Rev. Smith, and that the women had done nothing wrong. The men in the kitchens and the ward surgeons made their own case for retaining Amanda and Libbie. Fuller gave Amanda a letter from her father, announcing that he was coming to serve as chaplain for the hospital. Her father, though unaware of the charges made against his daughter, clearly wanted Amanda to stay, and his presence, Fuller claimed, would surely prove that nothing immoral was going on. ${ }^{57}$

Fuller offered a compromise. He suggested that the young women be returned to No. 14 temporarily to show the Commission's confidence in them-and in him. He declared that if the Commission would not agree to this, he would take it as a personal insult and "he was done with the Commission forever.",58

Mrs. Smith, Mary, and Mr. Ewing were persuaded to leave Amanda and Mary Kibbon, a temporary replacement for Libbie, at the hospital to await a decision from Wittenmyer. Amanda agreed to stay, although she hoped to be able to leave soon. Mary, with full confidence in her sister, returned to Louisville. There she wrote a detailed account of the interview with Dr. Fuller and suggested that Wittenmyer make the final decision "without saying a word to Mr. Smith."

Wittenmyer directed Amanda and Libbie to stay at No. 14. Some Christian Commission delegates were not happy with the decision. One unsuccessfully plotted with a chaplain to tell the local provost marshall that Amanda was no longer in the employ of the Commission and to have her expelled from the war zone without informing Wittenmyer. ${ }^{60}$

The incident was trying for both Mary and Amanda. Mary, who was "troubled and perplexed," reported that Amanda had

\section{Ibid.}

58. Ibid.

59. Mary seems to have believed as Dr. Fuller did that Mr. Smith or the chaplain had "warped" Wittenmyer's "mind and caused all the trouble." Mary Shelton, Louisville, KY, to Annie Wittenmyer, 1/26/1865 (underscoring in original); and Mary Kibbon, Nashville, TN, Hospital No. 14, to Annie Wittenmyer, $1 / 25 / 1865$, both in Wittenmyer Papers.

60. The delegate suggested bringing Amanda's old friend Mr. Russell from the Louisville Christian Commission Station into the plot. Russell may not have been willing to participate. In any case, it was never carried out. Bro. George, Nashville, TN, to Bro. Loyd, 2/12/1865, Wittenmyer Papers. 
"wept convulsively" over the situation. Both seriously considered leaving the diet kitchen work over what they felt were unfair, unreasonable, and unfounded charges. At one point, Amanda's anger at being "slandered" primarily by "chaplains" who were "hanging around" the Christian Commission Headquarters in Nashville was so great that she decided to take a job with the Sanitary Commission, a competing, secular relief organization. Mary received an attractive job offer that would have involved traveling to Europe, and she threatened to take it if Amanda was sent home. In the end, Mrs. Smith and Wittenmyer supported the sisters. The Christian Commission delegates and chaplains in the area were quieted, perhaps by the presence of Orville Shelton. The sisters turned down alternative offers and remained in the service of the Christian Commission, demonstrating their toughness and dedication to work that they thought was important.

After the controversy and Orville Shelton's arrival, the relationship between the managers and the surgeon-in-charge quickly deteriorated. Amanda's position became more and more unpleasant. By February, she was embarrassed to admit that Dr. Fuller, who had gained her confidence, was a "finished flirt." Her greatest desire was to "be away" from him. By April, she was even more eager to leave, and her opinion of Dr. Fuller had fallen further. She charged that he made the hospital "very uncomfortable" for her, provided poor accommodations for her father, and malevolently deprived the diet kitchen managers of staffing they needed to do their work. Living well in the field in spacious rooms, he was stealing funds meant to feed the soldiers and allowing "rats" to "eat dead men." Such experience matured Amanda, who wrote, "I have lived more myself and seen more of life than in all the former years." ${ }^{\prime 62}$

Finally, Libbie and Amanda were able to leave No. 14 to establish kitchens in hospitals for soldiers newly liberated from southern prisoner-of-war camps. Mary, overjoyed that Amanda was leaving, came to escort them east. She wrote in her diary,

61. Mary Shelton, Louisville, KY, to Annie Wittenmyer, 1/26/1865; Mary [Shelton], Memphis, TN, to Annie Wittenmyer, 3/9/1865, both in Wittenmyer Papers. 62. Amanda Shelton, Diary, 2/11/1865, 4/7/1865. 
"Left no. 14 forever and thank God the girls are gone from there," leaving all their troubles behind. ${ }^{63}$

As they traveled toward Washington, D.C., they heard a rumor that Lincoln had been shot. In the capital, they realized it was true, and went to see the martyred president lying in state. The group then pressed on for Berry Hill Hospital in Wilmington, North Carolina, where Mary helped Amanda and Libbie establish a new kitchen. Mary then returned to Washington, D.C., where she was a regional administrator. ${ }^{64}$

With the war over, Amanda and Libbie enjoyed the spring in the "sunny south." Working in the kitchens, they also had time to explore the landscape now in early bloom, clam, ride horses, and wade in the ocean. Their hospital duties were light, and patients were fewer and in better shape. Amanda was particularly pleased to have more opportunities to converse with the patients than she had had in earlier assignments. While meals were being prepared, "the boys" would gather at the kitchen window and beguile the managers with stories. Amanda also did some relief work with poor whites and emancipated slaves in the community. She enjoyed her stay and learned much about military life, southern culture, and the experience of poor whites and emancipated slaves. She felt that this was a pleasant assignment, concluding that they "were very pleasantly situated.. ${ }^{\prime 65}$

As Amanda enjoyed the balmy spring in North Carolina, Mary was in far less enviable circumstances. Soon after she returned from North Carolina, Mary contracted a serious fever with a terrible "pain" in her "bowels" that incapacitated her for weeks and made her long for her mother and her home. ${ }^{66}$

Her administrative duties, too, were causing her discomfort. Mary, now regional supervisor in the Eastern Department, at times seemed overwhelmed by the difficulties she encountered with managers in the Washington area. On one occasion, when she felt it was best to move a kitchen administrator to a different

63. Mary Shelton, Diary, 4/10/1865.

64. Amanda Shelton, Diary, 5/27/1865; Mary Shelton, Diary, 4/15-5/7/1865.

65. Amanda Shelton, Diary, 5/27/1865.

66. Mary Shelton, Washington, DC, to Annie Wittenmyer, 6/5/1865, Wittenmyer Papers; Mary Shelton, Diary, 5/29-6/8/1865. 
hospital, the manager, her fellow workers, and even the surgeon resisted her reasonable request. Mary was perturbed. She felt that their objections were attributable to the manager's skill on the "melodeon" and their concern that her replacement was not "stylish" enough. Mary's depression and frustration even haunted her dreams. In general, she was becoming increasingly uncomfortable in Washington, D.C., where the shrinking field left two of Wittenmyer's regional managers with overlapping responsibilities and developing tensions.

The eldest daughter and now the eldest surviving Shelton child, Mary was also troubled by her obligations to her family. She worried about her mother, who was still grieving over a son lost during the war and worrying about two daughters and a husband away from home. Mary, "longing for home and its quiet, and comfort," considered her mother's needs, her own homesickness, and the swiftly decreasing number of hospitalized soldiers and saw little need for her continued presence in the field. ${ }^{68}$

In June 1865 Mary received permission to leave the Commission's service. As she faced her departure, she found that her feelings were ambivalent. "One week from now will be with the loved ones at home, and yet so sad to go," she wrote, obviously regretting leaving her friends and the work that she had loved. ${ }^{69}$

With Mary at home to comfort their mother, Amanda was able to remain in the field a few months longer. From Berry Hill Hospital in Wilmington, North Carolina, she moved to Sickles Hospital in Alexandria, Virginia, at the beginning of July. She found this to be a far less pleasant assignment. With fewer and fewer men in the hospitals, there was less and less for her to do. In August 1865 Wittenmyer and the hospital administrators argued over whether the women's services were still needed in the hospitals. Amanda expressed dissatisfaction with the hospital administrators and the hospital itself. She wanted to return home. ${ }^{70}$

67. Mary Shelton, Washington; DC, to Annie Wittenmyer, 6/3/1865, 6/21/1865, Wittenmyer Papers; Mary Shelton, Diary, 6/21/1865.

68. Mary Shelton, Diary, 6/7/1865.

69. Ibid., 7/16-18/1865.

70. Amanda Shelton, Diary, 8/5-13/1865. 
BY THE FALL OF 1865, the war had ended, and Mary and Amanda had both returned home. Their service had lasted for a relatively short period of time, but both felt that it had been the most eventful period in their lives. Working alongside of and in fact training and supervising male soldiers, caring for, comforting, and consoling suffering strangers-and receiving respectable salaries to do it-made a deep impression on them. After participating in the war, what would their postwar lives be like?

Mary had been sad to leave the field but cheered up on the journey home. When she arrived in Mount Pleasant, she was delighted to be home with her family. ${ }^{71}$ There the wartime "Field Superintendent Diet Kitchens in the Department of the Mississippi, U.S.C.C." was just another unmarried Iowa woman who did her share of the dull and physically taxing labor of a nineteenth-century household." She washed clothes by hand, ironed in the heat of the summer, baked, made and mended clothes, canned food, hung wallpaper, sewed rag rugs, and provided child care for her little brother Charlie. Household labor was interwoven with social and religious activities. She spent time with friends, attended church, and read the Bible daily. Her interest in participating in philanthropic activities continued; she did some writing for Wittenmyer and organized and participated in a fair to benefit an asylum for the orphans of soldiers and visited the institution. ${ }^{73}$

Just as male returning Civil War veterans experienced some difficulty adjusting to life at home after the war, so, too, did Mary. Compared to her interesting wartime work, her life seemed mundane; it made her "gloomy" that "days pass with nothing to do but housework." "I feel I ought to be at work. . . . Active Christian labors I must have. ${ }^{\prime 74}$ The war had offered her many instructive, enjoyable, exciting, tragic, and inspiring experiences, but they were different from those her cohorts on the

71. Mary Shelton, Diary, 7/21/1865.

72. Mary put this title at the end of a letter to Wittenmyer as a kind of joke. She followed it with the comment, "Keep out of the way of my title. It is about as formidable as yours." Mary Shelton, Memphis, TN, to Annie Wittenmyer, $12 / 31 / 1864$.

73. Mary Shelton, Diary, 8/1-31/1865.

74. Ibid., 10/5/1865. 
home front had experienced. Having lived much, she also had the feeling that in some ways life had passed her by. When she turned 25 on September 23, 1865, and looked back on her life, she felt out of step with women who had remained at home. "None of those eventful affairs have marked my life that girls usually know in twenty-four years."

Her lucrative work in the field having ceased, she was also faced with the economic necessity of doing something to "make some money." She reluctantly agreed to employment at the end of October in a Burlington, Iowa, school. The day before she was to return to the classroom she wrote, "go into school tomorrow and dread it." She consoled herself with the thought that "God will doubtless give me every needed grace, but I prefer anything to teaching." She had cause to be apprehensive. She found a classroom with more than one grade, with discipline problems, and with, at one point, 80 students. On her second day of teaching she reiterated, "O! If I could do anything but teach." On several occasions she had to turn down more intellectually challenging or rewarding activities because she had to teach to make money.

Having successfully performed other professional labor that she enjoyed far more during the war, it is not surprising that Mary would be frustrated by the lack of economic opportunities the postwar world offered women. Mary indicated early in her service with Wittenmyer that she preferred work as her secretary to teaching. During that period she was thinking and talking about the issue of "women's rights" and "woman and her duties." Her first references to the subject do not indicate what her opinions were, but by the end of the war she was clearly an

75. Ibid., 9/23/1865.

76. Ibid., 10/5/1865, 10/31/1865, 11/2/1865. The school was most likely Burlington High School. See Louise R. Noun, Strong-Minded Women: The Emergence of the Woman-Suffrage Movement in lowa (Ames, 1969), 75. Mary received an invitation to join Wittenmyer in Des Moines, but could not go because she was teaching. Mary Shelton, Diary, 11/8/1865. When Frank Moore was assembling his classic book on women in the Civil War, he contacted her and asked for information on her warwork to include. Mary was willing, but apologized that as she was working as a teacher (to help put her sister through college), she would not be able to do it soon or without compensation. Amy Leigh, Archivist, Duke University, "Re: Frank Moore Papers," personal e-mail, 8/4/2003. 
advocate of women's rights. When a male escort made a broad statement critical of women after a lecture by Anna Dickinson, a popular speaker who supported the Republican Party and the rights of women and African Americans, Mary was so insulted that she mentioned it in her diary and in a letter to Wittenmyer. ${ }^{7}$

After the war, Mary and Amanda both read works discussing the women's rights issue. On one occasion they shared "the 'Mills' article on 'Enfranchisement of Women'" as they prepared dinner, and "it was received with great applause." In the fall of 1865 , as Mary struggled against what she called "school drudgery," she dutifully taught at the school, but then spent her free time reading intellectual discourses on women's rights. Reading such works helped her become "more and more settled in my views of life every day." ${ }^{\prime \prime 8}$

A letter attributed to Mary that appeared in the Independent, Theodore Tilton's popular religious journal, on January 24, 1867, shows that she saw woman suffrage as the remedy for the lack of economic opportunities for women. In the letter she rejected as unrealistic admonitions that women must remain as "angels in the home." In fact, she pointed out, women were compelled to participate in the "rough outer world" out of economic necessity even though they were at a great disadvantage in attempting to support themselves. She also lamented that few occupations were open to women, and those that were, even professional positions such as teaching, paid women only a fraction of what men were paid. She concluded that such conditions led "all our reading, thinking women" to be "on one side of this great question," to "desire and confidently hope ere long to have the ballot" and bring about "the dawning of better days." In addition to public writings on the subject of women's rights, Mary's convictions led her to help organize the Burlington Woman Suffrage Association and to serve as its first secretary. In that capacity she met and entertained Susan B. Anthony when she visited the region. ${ }^{79}$

Mary's interest in women's issues and her dedication to continuing missionary work similar to the work she had per-

77. Mary Shelton, Diary, 2/1/1864, 4/3/1864, 6/9/1865; Mary Shelton, Washington, DC, to Annie Wittenmyer, 6/10/1865, Wittenmyer Papers.

78. Mary Shelton, Diary, 12/6/1865, 11/18/1865, 11/26/1865, 11/30/1865.

79. Noun, Strong-Minded Women, 75-77. 
formed during the war led her to actively support missionary initiatives led and staffed by women. She held leadership roles in the Women's Foreign Missionary Society of the Methodist church, a society devoted to bringing women to foreign mission work with the objective of converting other women. She was the first president of the Des Moines branch of the society, contributed articles to its magazine, the Women's Missionary Friend, and gave addresses on behalf of its work. ${ }^{80}$

Throughout her life Mary was well regarded by members of her church and those at the college where she had received her education. In 1880 she became the first woman to serve as a trustee of Iowa Wesleyan College, an office she held for more than two decades until $1903 .^{81}$

Mary's involvement in educational, religious, and political reform was blocked in her immediate postwar life by her need to make money. That impediment was removed by her marriage to Emory S. Huston, in Eddyville, Iowa, August 18, 1869. By 1870 , the two were living in Burlington, where the census lists Emory as county auditor. ${ }^{82}$

The work that Mary had performed during the war, both life-saving and life-changing, remained important to her. She kept in touch with some of the men she had met or cared for in hospitals and continued to have fond memories of those "blessed hospital days." Toward the end of her life she and her husband moved to Washington, D.C., where she died in January $1909 .^{83}$

AMANDA remained in the field for months after the fighting ended. She finally returned to Mount Pleasant on August 26, 1865. Her diary entries ceased between August 1865 and July 1866, but Mary recorded Amanda's return and her life during that period. Amanda, like Mary, was happy to be home with her

80. Historical Sketch and Alumni Record of Iowa Wesleyan College (Mount Pleasant, 1917), 141; Frances J. Baker, The Story of the Woman's Foreign Missionary Society of the Methodist Episcopal Church, 1869-1895 (1898; reprint, New York, 1987), 55.

81. Baker, Story of the Woman's Foreign Missionary Society, 55.

82. U.S. Census Office, Population Schedules of the Seventh Census of the United States, Iowa, Des Moines County, Ancestry.com, www.ancestry.com (accessed 5/23/2004); Historical Sketch and Alumni Record, 141.

83. Moore, Women of the War, 233; Historical Sketch and Alumni Record, 141. 
family, and they were happy to have her with them. Mary recorded that "Manda is so full of life that we are cheerful all the time," and that those days were "full of joy and blessing." ${ }^{84}$

When Amanda does begin writing in her diary again in the summer of 1866 , the entries suggest that she, too, must have had some sense of dislocation after returning from her exciting and demanding wartime career to her home town. She noted that thinking of the past brought to her mind "sorrow and disappointment," because "so many ... old friends" were "with the dead and so many of the living having proven unworthy of the name 'friend.'

Amanda returned to her diary after she began working in July 1866 as a bookkeeper in an insane asylum in Mount Pleasant. Amanda was one of the growing number of middle-class women moving into clerical positions in the postwar period. Her army hospital work may have helped Amanda fit easily into the asylum organization. As in the diet kitchens, she had official and unofficial duties. Officially, she wrote reports on the "condition of the sick" and prepared patients' bills. Unofficially, she spent time in the wards with the patients, attended dances, and did crafts.

Similar in many ways to the work she did in hospitals, the work satisfied Amanda's desire for service-oriented work and new experiences. She wrote that she found "life here almost as full of incidents as army life," and that "my life is not quite useless." Such work filled her time, but she did not intend to make it her life's work. A "few months experience will do me good," she wrote, but she did "not intend to stay here long. ${ }^{186}$

Within five years, her life would change again when she married Samuel F. Stewart on the day after Christmas in December 1870 . Stewart was a Civil War veteran who had served under General George Thomas in some of the same locations where Amanda had worked in diet kitchens. They had two

84. Mary Shelton, Diary, 8/26-30/1865.

85. Amanda Shelton, Diary, $7 / 8 / 1866$.

86. Ibid. 7/8/1866, 7/13/1866, 8/3/1866, 9/9/1866. The portions of Amanda's diary dealing with work in the insane asylum have been reprinted in Wood,

"My Life Is Not Quite Useless," 2-13. 
daughters, Helen Shelton Stewart, born in August 1873, and Lucy Shelton Stewart, born in September 1875. ${ }^{87}$

As she had while serving as one of the first diet kitchen managers during the war, Amanda blazed new trails for women after the war. In Eddyville, she served as superintendent of schools. She also ran a private normal school in Chariton, Iowa, when her daughters were small. ${ }^{88}$ In 1889 the family moved to Evanston, Illinois, where Samuel was an agent for the Iowa Homestead, which he co-owned, and their daughter Lucy attended Methodist-affiliated Northwestern University. ${ }^{89}$

Amanda's war service remained important to her throughout her life. She lectured on her unusual and pathbreaking wartime work to interested groups, including those gathered for a reunion of Spanish-American War veterans. Her remarks noted the daring and discomfort, the trials and tribulations of her work in hospitals, but they also suggest the professional nature of the work she had done in hospitals in introducing "theories of efficiency" that had been carried out in the Spanish-American War. Amanda remained involved in "philanthropic, educational, and literary work" for the remainder of her life. She died in Evanston, Illinois, on February 16, 1912. ${ }^{.0}$

Amanda's daughter Lucy continued to live in Evanston. She assisted her father in editing various periodical works and in commemorating her parents' work in the war well into the twentieth century. In 1916 she wrote a tribute to the life of Annie Wittenmyer for the Woman's Christian Temperance Union, a task she felt sure her mother, who had greatly respected Wittenmyer, would have done if she had lived longer. ${ }^{91}$

87. Historical Sketch and Alumni Record, 146; Lucy Shelton Stewart, Rewards of Patriotism: A Refutation of the Present-Day Defamations of the Defenders and Preservers of the Union in the Civil War and an Exposition of the Cause which They Overcame (New York, 1930), facing page 122.

88. Historical Sketch of Iowa Wesleyan College, 146; Wood, "My Life Is Not Quite Useless," 3.

89. "Lucy Shelton Stewart," Evanston Review, 8/2/1962.

90. Amanda Shelton Stewart, Address, 18-19, Shelton Family Papers, Iowa Wesleyan University, Mount Pleasant, Iowa; Historical Sketch and Alumni Record, 146. 91. Wood, "My Life Is Not Quite Useless'," 5; Lucy Shelton Stewart, Lest We Forget: Annie Wittenmyer, First President of the National Woman's Christian Temperance Union (Evanston, IL., 1916). 
Lucy was as devoted to the Union cause as her mother had been. Working with her then octogenarian father, she wrote The Rewards of Patriotism in reaction to what she felt was a growing tendency to glorify the southern role in the Civil War. The year after the publication of the book, and nearly two decades after her mother's death, she read an address her mother had written and presented years earlier to the Mississippi Valley Historical Association. $^{92}$ Realizing the significance of her mother and aunt's Civil War experiences, she and her sister Helen donated the wartime diaries to the University of Iowa, where they can be found in the libraries' Special Collections Department today.

FROM 1861 TO 1865 American women mobilized themselves into the great army of alternative laborers that was needed to fuel the war machine. Motivated by patriotism and compassion, they entered professional occupations not open to them in times of peace. The Civil War experiences of Mary and Amanda Shelton vividly illustrate what drew women into such occupations and what satisfaction and rewards they derived from them. Their stories also illustrate the obstacles they encountered as they entered the public sphere and how their growing abilities and confidence allowed them to adapt to and successfully function in new and sometimes conflicting bureaucracies.

For these women, the wartime work was exhilarating and rewarding, and it changed them. Having successfully adapted to a wartime world of increased freedom, power, salaries, and status, they returned to homes that had not changed as much during the war as they had. Rising to new challenges, they forged new paths for women in education, temperance, efforts for woman suffrage, and foreign missionary work by women for women, and in support of colleges that offered early opportunities for coeducational instruction.

92. Lucy Shelton Stewart, Rewards of Patriotism; idem, Address. 
Copyright of Annals of Iowa is the property of State of Iowa, by \& through the State Historical Society of Iowa and its content may not be copied or emailed to multiple sites or posted to a listserv without the copyright holder's express written permission. However, users may print, download, or email articles for individual use. 